\title{
PROPOSALS FOR DEFINING AND IMPLEMENTING THE RESALE RIGHT IN THE ROMANIAN LAW SYSTEM
}

\author{
Tudor-Vlad SFÂRLOG \\ "Lucian Blaga" University, Sibiu, Romania \\ tsfarlog@yahoo.ro
}

\begin{abstract}
With the present scientific endeavour, we propose a new doctrinal approach on the resale right in terms of both legal acts that generate a resale right and how the regulation of resale rights regulates social relationships between a holder of the right and his/her debtors. When preparing the study, we consulted the doctrine of speciality, case law and objective law.
\end{abstract}

\section{Keywords: resale right, civil law, intellectual property}

\section{Introduction. Defining the concept}

Resale right was defined in art. 1 , par. (1) in Directive no. 2001/84/EC [1] and the definition proposed by the law giver has been deeply criticized in doctrine [2]. Thus, we assent to the definition proposed by Prof. Bodoașcă, pursuant to which the resale right is that possibility granted to a right holder, within limits of public order and good morals, to claim and receive from persons assigned in law a certain amount of money, representing a certain percentage from the price gained from selling his/her original work of graphic or plastic art or of a photographic work, after such a work has been alienated by him/her for the first time, and to be informed on the location of his/her work and, whenever needed, to resort to the state's coercive power to protect such prerogatives [3]. As shown [4], [5], the resale right is a creation of the French law giver and it comes to support material interests of authors, as it is predicated on the inequity [6] between the price to which beginner artists were forced to sell their works and the exploitation of such works by tradesmen at much higher further prices. This argument is also supported by the fact that, at the beginning of their career, artists will sell their works at a very low price. Then, due to their rise in fame, their works will be sold at much higher prices and the benefits of such a resale will only go to subsequent owners. This is how the resale right appeared, based on the principle of equity, according to which, an artist is entitled to a percentage from the resale price of his/her work. After the Berna Convention on the resale right and pursuant to modern national laws, holders of resale rights are only authors of graphic works or plastic works and photographic works.

\section{Proposals for redefining the resale right in the Romanian system of law. \\ Pursuant to legal regulations, the resale right is a part of the economic rights of authors, bearing all traits provided in law. Thus, economic rights of authors are recognized in art. 1, par. (1) in Law no. 8/1996, which expressly stipulates the classification of rights that stem from the existence of a work creation into moral}


attributes and economic attributes. Moreover, the law giver dedicates the second paragraph of the same article to the close connection between authors and moral attributes and economic attributes. The law giver's formulation, "this right is connected to an author's person and it entails moral attributes and economic attributes" outlines, on one hand, some of the defining traits of authors' rights and, on the other hand, it creates equivocalness as regards the law giver's option pertaining to the contents of rights or, as applicable, the contents of authors' rights. Thus, as shown [7], the lack of coherence in the law giver's enunciation creates ambiguity in interpreting the law giver's option as regards the dualist or monist theory on the content of authors' rights [8]. If an author's moral rights represent the spiritual connection between the author and his/her work, and they are inalienable and perpetual, economic rights of authors grant a work's author the option to authorize certain economic means to capitalize on his/her work and he/she has as primary argument an author's entitlement to economic benefits, according to his/her own belief, from economic gains produced by his/her work. Thus, from a conjunct analysis of articles 1, 2 and 12 in Law no. 8/1996 and provisions in the Civil Code, there results that authors' economic rights bear the same traits as economic civil rights [9], and provisions in the Civil Code on the matter are supplemented by provisions in Law no. 8/1996. Thus, from an analysis of legal texts, we derive that authors' economic rights have a nature that is essentially personal, as they are connected exclusively to an author's person. Pursuant to art. 12 in Law no. 8/1996, "the author of a work has the exclusive economic right to decide if, how and when his/her work is to be used, including that of consenting to his/her work being used by others". Thus, the exclusive nature of economic rights has in view mainly an author's vocation to decide if a work will be exploited and how it can be exploited. Moreover, from a logic and legal analysis of the provisions on transferring economic rights of authors (art. 39-91 in Law no. 8/1996), there results that the exertion of economic rights is, in principle, alienable. Still, moral rights and economic rights of authors co-exist based on one single connection whose legal protection ensures the social framework needed for advancement through intellectual creation. We therefore put forward the thesis that to assent to one of the two theories - monist or dualist - on the content of authors' rights or right, as applicable, must respond to the following requirement. Is there one single complex author's right which safeguards both moral attributes and economic attributes of authors? In this case, the differences between moral attributes and economic attributes make it difficult to fuse these two into a single complex right, as is it rather an institution, the institution of authors' rights.

Pursuant to art. $21^{5}$ par. (1) in Law no. $8 / 1996$, the author of an original work of graphic art or plastic art or of a photographic work benefits from a resale right which represents the entitlement to receive a share from the net sale price gained from any resale of the work, subsequent to the first transfer of the work by the author, as well as the right to be informed on the whereabouts of his/her work. Thus, the entitlement of an author to collect a percentage from the net sale price after the first resale exceeds the principle of equity, as shown [10], since this regulation protects the moral interests of authors in the context of a work resale and not of its appreciation. At the same time, the legal regulation that only resale is a source of resale rights can be improved, given the myriad of "solutions" that can be used to by-pass legitimate interests of authors.

A debated issue in doctrine is given by legal acts to which resale rights can be applied. Thus, pursuant to art. 21 par. (2) in Law no. 8/1996, the resale right applies to all acts of resale that involve any art dealer. In this group we include art buyers, art agents, art galleries etc. We consider that 
the two conditions are cumulative. As shown [11], the enunciation is not only lacking, but it can also generate uncertainties among beneficiaries and even issues of non-unitary case law, as it cannot properly implement a principle of equity. The plethora of possibilities at hand prior to concluding a sale through which an act of sale cannot be called an act of resale, in order to be a generator of resale rights, deprives the legitimate economic interests of an author from their legal safeguard. Furthermore, by conjoining provisions in art. 21 par. (1) with those found in the Directive, we deduct that the first sale must be made by the author. But in case an author has transmitted an item by exchange or donation, we can reasonably deduct that such a work will no longer be protected by the resale right, as such a situation can no longer be achieved.

As a follow-up to the extreme situation that made it necessary to give a law on resale rights in France, in 1920, we put forward the opinion that national laws have not modernized the implementation of the principle of equity according to the requirements of our times. Thus, foremost, how a holder of resale rights is entitled is profoundly incorrect and illegitimate, giving rise to situations of enrichment without just cause. Secondly, the legal regulation pursuant to which certain acts generate or do not generate resale rights can be improved. Indeed, pursuant to the principle of equity, an author's resale right should appear only in the added value of a work. Moreover, except for inheritance deeds, the principle of equity should not make a distinction between the means by which a property is transmitted, since the essence in the principle of equity contemplates the plus value generated by an author's celebrity after selling the work and a redistribution of the value it generated. At the same time, this principle is also called forth in art. 3 of the Directive. Therefore, in our opinion, any legal act must be a generator of resale rights, except for mortis causa, through which ownership over a work protected by resale rights is transferred, if such a work has generated an added value since its latest transfer. This is how we appreciate the principle of equity would be eloquently implemented, thus achieving a fair redistribution of economic benefits gained from the creation of a work protected by the resale right. It would no longer be possible to elude the resale right in the benefit of an author by disguising a purchase deed under the mask of exchange or a deed of another nature. The means by which authors' rights can be relevantly achieved in cases of other means of property transfer outside sale can be attained by enforcing the provisions pertaining to the author's being informed on his/her work in art. $21^{5}$ par. (1) and art. 21 par. (6). Thus, if the transfer of ownership in a work protected by the resale right is made through an exchange agreement, the value to which the work will be valuated shall be the value of the item against which it was exchanged, and the price can therefore be calculated. If a work is transferred through an act of donation, the item can be appraised by an expert. In both cases, the resulted value will be deducted from the previous value at which the item was acquired and there will result if such a deed generates a resale right, to the extent to which such an item was appraised. In such a paradigm, we can state that, except for sale contracts, the resale right appears under condition subsequent only if, after having met all conditions, there results that the item has recorded a financial appreciation since the last transaction. Concurrently, the setting of minimum and maximum thresholds for the amount calculated as an author's entitlement provided in art. 21 par. (4) in Law no. 8/1996 can generate inequity. Firstly, setting a maximum threshold, established in the same article, can generate unfair situations in a context where the appreciation of a work's value can be significantly higher and the redistribution of compensation would be limited because of 
the maximum threshold required in law, particularly if we consider that, usually, the more expensive an item is, the slower its circulation in the civil circuit. At the same time, not only that the author of a very valuable work would not gain more than the author of a less valuable work, which falls within the upper threshold established in legal regulations, but, in statistical terms, the author whose work is of a lesser value would gain more, given the legal operations of property transmission which are likely to be more numerous.

The gaps in the law giver's enunciation are not confined to applying the principle of equity, but they are also revealed in relation to resale right holders. Thus, pursuant to art. 21 par. (7), the law giver stipulates that the resale right cannot be subjected to any waiver or alienation. Still, as shown [12], there are several natural persons or legal entities that can become holders of resale rights.

\section{Conclusions}

We therefore consider that the resale right must be revised as a whole for a fair implementation pursuant to the principle of equity. For this, we formulate the thesis that the implementation of the principle of equity must be revised $a b$ initio, starting from the core of the institution, id est that of redistributing pecuniary benefits between the author and subsequent owners of a work as a result of an increase in the value of the work due to its author's reputation. Thus, in our opinion, the resale right should be redefined as that possibility granted to the holder of resale rights, within limits of public order and good morals, to claim and receive an amount of money from persons designated in law, representing a certain percentage from the added value to the original work of graphic art or plastic art or to the original photographic work in relation to the last transfer of the work. As we have shown, such a regulation would grant an author the legitimate protection of his/her economic interests and it would avoid, $a b$ initio, situations where an author would not be entitled to capitalize on the resale right because of a lack of realizations unfairly provided in objective law.

In conclusion, we consider that the resale right regulation does not match requirements caused by the fair safeguard of authors' economic rights and we propose the harmonization of the law in order to offer a fair legal framework that is needed in order to conduct creation activities.

\section{References}

[1] According to Directive no. 84/2000/EC, the resale right is defined as "an inalienable right which cannot be waived, even in advance, to receive a royalty based on the sale price obtained for any resale of the work, subsequent to the first transfer of the work by the author."

[2] T. Bodoașcă, Dreptul proprietății intelectuale), p. 54 ff.; V. Roș, Dreptul proprietății intelectuale, Curs universitar, p.143 ff.

[3] T. Bodoașcă, Unele contribuții la studiul regimului juridic al dreptului de suită, in RRDPI, no. 3/2009, p. $35 \mathrm{ff}$.

[4] V. Roș, Dreptul proprietății intelectuale, Curs universitar, Bucureşti, p. 142.

[5] Y. Eminescu, Dreptul de autor, Bucureşti, 1994, p. 165 ff.

[6] V. Roș, op.cit. The presented illustration that generated A. Hesse's law initiative is eloquent.

[7] T. Bodoașcă, Dreptul proprietății intelectuale, Ediţia a II-a, revizuită, Editura "Universul Juridic", Bucureşti, 2012, pp. 17 ff.

[8] For details, see also Y. Eminescu, Dreptul de autor, Editura "Lumina Lex", Bucureşti, 1997, p. 142 ff., as well as V. Roş, Dreptul proprietăţii intelectuale. Curs universitar, Editura "Global Lex", Bucureşti, 2001, p. 107 ff.

[9] T. Bodoașcă, op. cit., p. 46 ff.

[10]T. Bodoașcă. Unele contribuții la studiul regimului juridic al dreptului de suită in 
RRDPI, no. 3/2009, p. 35 ff.

[11] Ibidem, p. 15

[12]T. Bodoașcă, Dreptul proprietății intelectuale, p. 56. 